\title{
21 REGULATING DEATH AND FUNERAL RITES IN A SECULAR BUT RELIGIOUSLY PLURALISTIC SOCIETY: THE CASE OF THE CORONER LAW SYSTEM IN LAGOS STATE, NIGERIA
}

\section{Danoye Oguntola-Laguda ${ }^{1}$}

\section{INTRODUCTION}

In Nigeria, secularism has been the determining principle for government engagement in religious matters. Section 10 of the 1999 Constitution of the Federal Republic of Nigeria substantiates this claim. However, the realities in the country suggest a religious pluralised environment in which competing religious traditions contest for space and influence of government policies. The political class have also appropriated religion as a tool of negotiation during electioneering campaigns and process. ${ }^{2}$ Consequently, the policies and engagements of government have been influenced by religious beliefs and traditions towards the people and international organisations.

Such was the case of the controversy over Nigerian membership of Organisation of the Islamic Conference (OIC) in the 1980s, when the military government had to jettison the planned membership due to protest from the Christians under the auspices of the Christian Association of Nigeria (CAN). The Christian group believed that joining OIC was the beginning of the Islamisation of the country. Muslims in Lagos State also protested the government return of schools to missionary groups in 1999. Muslim groups, such Ahmaddiyah and Ansar-UdDeen believed this constituted a process of marginalisation of Muslims in the state, as they lacked the capacity to manage such schools at that time.

Another recent controversy in Lagos State was the reactions of Muslim communities in the state to the Coroner Law System (CLS). The CLS was passed into law in 2007 by the Lagos State House of Assembly. ${ }^{3}$ The law was to check cases of questionable deaths and regulate funeral rites and processes in the state, especially in public institutions such as health centres and in cases of deaths of individuals in police custody. The law demands a postmortem examination of all corpses to determine the cause of death. This would necessarily delay

1 Department of Religions and Peace Studies, Lagos State University, Ojo, Lagos, Nigeria.

2 See Oguntola-Laguda D. 2015. “Religion, leadership and struggle for power in Nigeria: A case study of the 2003 presidential election in Nigeria", in Coertzen P, Green MC and Hansen L (eds). Religious Freedom and Religious Pluralism in Africa: Prospects and Limitations. Stellenbosch, South Africa: African Sun Media, 143-156.

3 Lagos State Coroner Law System. 2007. Lagos: LSPC, August. 
funeral process of dead Muslims, who are supposed to be buried immediately after death. This led to protests against the CLS by Muslims communities in Lagos State.

The consternation that the CLS prompted in the Lagos State Muslim community is familiar to anyone who considers the religious and social context of grief and mourning of death around the world. Two decades ago, the American Christian political philosopher Nicholas Wolterstorff mourned the death of his son with the following words: "It's so wrong, so painfully wrong, for a child to die before its parents. It's hard enough to bury our parents. But that we expect. Our parents belong to our past, our children belong to our future. We do not visualize our future without them. How can I bury my son, my future, one of the next in line? He was meant to bury me." ${ }^{4}$ Wolterstorff's words upon the death of his child underscore the importance of funeral rites and the pain of death to every human being, especially in cases of the death of a child or a young person in the extended family. The German philosopher Martin Heidegger posited that death marks the end of life of any living thing. Its occurrence is not an accident, but a phenomenon with existential origins. For him, "Dying is not just an event that occurs to man at the close of his life, but a man's mode of being. For Dasein (man) is a being towards death. A being who begin to die the very day he was born and live all his life towards death." 5 This opinion suggests that death is a process humans need to prepare for and to which family and friends must inevitably respond.

In the African context, the Kenyan-born philosopher and theologian John Mbiti argues that death "is something that concerns everybody, partly because sooner or later, everyone personally faces it and partly because it brings loss and sorrow to every family and community". ${ }^{6}$ Mbiti underscores the basic implications of death to African people by explaining its universality and effects on the society, particularly as it comes with sorrow, grief and pain. Writing about the Yoruba of South-West, Nigeria, Bolaji Idowu, an anthropologist, posits that death is a creation of God. ${ }^{7}$ Death becomes an agent that God uses to call people whose time on earth is fulfilled back to the celestial world. The Yoruba people, like other Nigerian tribes, accept the reality of death with conviction that it is inevitable. However, the Yoruba also believe that death is only good for the aged, but that this is not the case when infants, youth and young adults die. Deaths of the aged are often celebrated, while those of children come with sorrow, grief and plenty of mourning. ${ }^{8}$ After death comes the funeral rite. To Nigerians, funeral

4 Wolterstorff N. 1997. Lament for a Son. London: SPCK, 16.

5 Heidegger M. 1967. Being and Time. Macquarie J and Robinson E (trans). Oxford: Basil Blackwell, 8.

6 Mbiti JS. 1982. African Religions and Philosophy. London: Heinemann, 8.

7 Idowu EB. 1996. Olodumare: God in Yoruba Belief. Sixth Edition. Lagos: Longman.

8 See Oguntola-Laguda D. 2014. “Conceptualizing Death In Yoruba Religion and Philosophy", in Oguntola-Laguda D (ed). Death and Life After Death in African Philosophy and Religions: A Multi Disciplinary Engagement. Harare: African Institute for Culture, Dialogue, Peace and Tolerance. 
rites are very crucial to the transition of the dead to the celestial world. It is a formal ritual that must be done with care and reverence; otherwise, the dead will not transit properly to the realm of the ancestors.

It is funeral rites and rituals like these that the Lagos State government now proposes to regulate through the Coroner Law System. This law is intended to regulate the process of funeral and burial of dead persons in the state, regardless of the religion that the deceased individual practised while alive. The aim of the CLS is to regulate and check cases of questionable death in public institutions such as police detention, prisons, and hospices. It is, however, the case that religious rights of some Nigerians have been infringed by the CLS. Muslims, in particular, have been the most affected by the CLS, as introduced in Lagos State in 2007. This law was used to investigate the death of people at the Synagogue Church of All Nations (SCOAN) in 2014 in a way that became a matter of controversy. Thus, Asonzeh Ukah, a Nigerian scholar of religion has argued that the SCOAN case "graphically illustrates the complexity and contradictions that exist in the relationship between ... the law and the state". ${ }^{9}$ Ukah observes that the state promulgates the law and enforces it through its agents for the good of the society. Further, religion also acts in public interest. This suggests that there is a symbiotic relationship between religion and the state.

Even so, this chapter proposes that the nature of religious pluralism in Nigeria does not support secularism. Instead, it allows competing religious epistemologies to seek government attention and interaction to further and protect the interests of particular religious communities. This chapter seeks to re-examine the religious landscape in Nigeria base on the concepts of pluralism and secularisation through analysis of the Coroner Law System introduced in Lagos State in 2007, as it has affected funeral rites for the dead in the multireligious environment of Lagos State.

\section{RELIGION, PLURALISM AND SECULARISM IN NIGERIA}

Religious groups do rise up in protest against government policies when its affects their tenets and doctrines. In Nigeria, there has been ecumenical opposition by religious groups on critical national issues. Such was the case with respect to LGBT rights issues in the Nigerian polity between 2011 and 2014, during the process of formulation and signing into law the Same Sex Marriage (Prohibition) Act, 2013. Muslims and Christian groups together supported the government position to ban homosexual activities in the country. In this instance, the law forbad LGBT advocacy and practices in the country, with jail sentences attached to its violation. The government position with regards to the SSMA was supported by all religious groups in the country, creating an ecumenical

9 Ukah A. 2015. "Prophecy, miracle, and tragedy: The afterlife of T.B. Joshua's ministry and the Nigerian state", in Coertzen P, Green MC and Hansen L (eds). Religious Freedom and Religious Pluralism in Africa: Prospects and Limitations. Stellenbosch: African Sun Media, 210. 
front against the LGBT communities in Nigeria. Indeed, the government, for its part, relied on religious perspectives and religious scriptures as a basis for the law, claiming that LGBT activities are sacrilegious. While LGBT rights are an issue distinct from the CLS, the point here is that even though Christians and Muslims are frequently on opposite sides in their reactions to government policies in ways that lead them to cite the secular nature of the country for their own protection, when they have a perceived common enemy, they are capable of alignment in support of the government.

Secularism in Nigeria, therefore, protects the religiosity of the citizens and allows for government engagement in religious matters. This explains why some scholars have argued that secularism in Nigeria is a ruse, as the government uses public funds to support religious practices. Sections 45 and 145 of the Nigerian Constitution, in particular, permit the government to provide an enabling environment for the practice of religions in the country. This was the justification for the building of both the Christian Ecumenical Centre and National Central Mosque in Abuja, as Nigerian Islamic scholar Is-haq Oloyede has concluded. ${ }^{10}$ It is clear, however, that there is a symbiotic interaction between political actors - specifically, government officials - and religious leaders and communities. Public funds have often been used to support religious rituals and rites. The situation has created paradoxes that demand critical evaluation in order to strike a balance between government policy formulation and their influence on religious communities, and how these paradoxes have shaped religious identities in Nigeria.

The term pluralism suggests that there are pluralities of particular ideologies in competition. The ideologies may be competing for political power, economic control or survival. It can be cultural, ethnic or tribal struggle for supremacy. ${ }^{11}$ Religious pluralism exists when more than one religious tradition is in competition with each other to gain converts, occupy spaces and seek attention from governments and the people. Gordon Melton, a sociologist, writing about religious pluralism in the West, claims that:

During the 20th century the West has experienced a phenomenon it has not encountered since the reign of Constantine, the growth of a significant visible presence of a variety of non-Christian and nonorthodox Christian bodies competing for religious allegiance of the public. This growth of so many alternatives religiously is forcing the West into a new situation in which the still dominant Christian religion must share its centuries old hegemony in a new pluralistic religious environment. $^{12}$

10 See Oloyede IO. 2014. "Theologising the Mudane, Politicising the Divine: The Cross Currents of Law, Religion and Politics in Nigeria", African Human Rights Law Journal 14(1):178-202.

11 See Oguntola-Laguda D. 2004. Religion: Study and Practice in Nigeria. Lagos: Free Enterprise Publishers.

12 Melton G. 1998. "Modern Alternative Religions in the West", in Hinnells JR (ed). A New Handbook of Living Religions. Harmondsworth, U.K.: Penguin, 594. 
Melton's position seems to describe aptly the religious plurality that now permeates the world. It is also relevant to the Nigerian situation, where traditional African religious cosmologies now compete with the cosmologies and epistemologies of Christianity and Islam.

Religious pluralism has made adoption of secularism a necessity for states where more than one religious ideology is prevalent. To my mind, it is to prevent government intervention in religious matters and remove the influence and consideration of religious creeds, doctrines and rituals in government policies and functions. It could be an attempt to avoid conflicts and promote religious tolerance among competing religious ideologies. It could also be to pursue the theories of sociologists like Peter L Berger, who has suggested that secularisation and modernity go hand in hand. ${ }^{13}$ The intention of the government of Nigeria, however, at least since independence in 1960, has been to try to be neutral among competing religious epistemologies. The aforementioned controversies over the attempt to join OIC and to return schools to missionaries indicate that such neutrality is subjective.

The reality is that the world is today neither wholly secular nor wholly religious, but religions have affected humanity both more positively and more negatively than has secularity. This is contrary to the position of Norwegian sociologists Inger Furseth and Pål Repstad, who argue that "secularization is the consequence of the differentiation process whereby system in society have become relative, independent from religious norms, values, and legitimations". ${ }^{14}$ Secularisation theories are attempts to account for how pluralism has re-shaped religious competitions and also reduced religion to private engagements into which the government should not intrude. In Nigeria, even though the Constitution suggests the existence of a secular state, the state has always appropriated religion in its policies and laws. This new order and the tensions that it has introduced between secularism and religion seems to be fertile ground for competing epistemologies.

In the opinion of sociologist of religion Kevin Christiano and colleagues, pluralism, by its nature, has "multiplicative effects". ${ }^{15}$ As they rightly note, ever increasing pluralism does undermine the absolute certainty that has been claimed by some religions, for example, the monotheistic faiths of Judaism, Christianity, and Islam and Judaism. Each new religion spawns more new religions, and these new religions continually arise to test this argument. Thus, Christiano and his fellow researchers conclude: "The more one becomes

13 Berger PL. 1997. "Epistemological Modesty: An Interview with Peter Berger", Christian Century 114:974. It should be noted that Berger, more recently, has questioned his own secularisation thesis in light of global religious resurgence. See Berger PL (ed). The Desecularization of the World: Resurgent Religion and World Politics. Grand Rapids, MI: Wm B Eerdmans Publishers, 1999.

14 Furseth I and Repstad P. 2010.An Introduction to the Sociology of Religion: Classical and Contemporary Perspectives. Aldershot: Ashgate.

15 Christiano KJ, Swatos WH (Jr) and Kivisto P. 2008. Sociology of Religion: Contemporary Development. Lanham, MD: Rowman and Littlefield Publishers. 
aware of more and more religious competition in a marketplace-like setting, the harder it becomes to assert that one religion contains all truth and that the others must be wrong. While it is certainly possible to make comparisons of better and worse, all-or-nothing rigidity simply doesn't hold up." ${ }^{16}$ Historically, Islamic nations (such as Iran, Pakistan, Bangladesh, Saudi Arabia) have not permitted the "free commerce" in religion that has become the hallmark of western democracy. In Africa, with its pronounced plurality of religions, it may be difficult for the state to engage in religious monopoly. In Nigeria, for example, the religious landscape is a free-market situation in which demand for spiritual solutions to spiritual needs determines supply. This is simply because of its religious pluralism. Thus, we can submit that monopoly is the antithesis of pluralism of the Nigerian situation.

Religious pluralism creates a marketplace of ideas in which absolute claims for "ultimate truth" are always at some degree of risk. The free-market situation gives freedom to the "buyers" to pick and choose among competing ideologies those that satisfy their "need" - materially and spiritually. Based on the free market model, Christiano and colleagues posit two theories on secularisation as follows: First, there is substantial body of evidence that pluralism of belief (including disbelief) has been intensified due to globalisation. Second, pluralisation forces us to make distinction between secularisation and what might be called new religious movements that may emerge or other world traditions may gain dominance over a traditional historical epistemology. ${ }^{17}$ The latter as was the case with Christianity in the West and African Traditional Religions (ATR).

It can be argued that, the market situation proposed by Christiano and his fellow researchers leads inevitably to syncretism. A "buyer" seeking solution to a multi-faceted problem may "shop" to meet his or her needs in different shops or supermarkets where all "products" seem to be available. This syncretism does not make the "buyer" irreligious, but rather makes it more interesting and challenging to choose among the competing "brands". New religious pluralism therefore provokes new syncretism, since it seems the religious "boundaries" have been broken down in the face of pluralism.

It can also be argued that religious pluralism necessitates secularisation, wherein appropriation of values in policies formulation can be done without religious justifications or rationales. In other words, under conditions of religious pluralism, religion loses its capacity to impose its beliefs and practices, and the society claims the capacity to lead its own destiny without religious participation. An individual will therefore be able to examine the ideologies, epistemologies, doctrines, tenets and practices of the competing religions and make his or her choice based on "needs". There are limitations here as to what

16 Christiano et al., Sociology of Religion, 75.

17 Christiano et al., Sociology of Religion, 74. 
will be available for sale. This goes to support the thesis of Furseth and Repstad, ${ }^{18}$ as well as Berger's thesis that "modern pluralism causes individual perception of reality to lose its self-evident status, becoming a matter of choice" ${ }^{19}$ However, Berger now claims that this does not necessarily lead to secularisation.

The Nigeria situations suggest an antithesis of Berger's secularisation thesis, especially when applied to state policies formulation. Government appropriates religious doctrines and values into laws as well as policies. This was the case in the SSMA 2013 against the activities of LGBT communities in the country. However, the situation with the CLS seems a bit different, as religious values were not considered in the formulation of the law. The implication is that the Nigerian government is inconsistent in its appropriation or non-appropriation of religious values.

\section{RELIGIOUS PLURALISM IN NIGERIA}

As stated earlier, the Constitution of the Federal Republic of Nigeria of 1999, like other constitutions before it, claims that the state is a secular state. The implication of this claim is that religion shall not be a factor in governance and the responsibility to lead, and that governance rests solely on the constitution, customs, traditions and culture of the federated "groups". However, the realities on ground suggest the contrary. Not only is the country religiously plural, but, as noted above, religion has continually been a factor in government policy formulation and implementation of laws in many cases. It is therefore apposite to consider the religious landscape in Nigeria, as a way to understand how religious diversities play out in the country and the promulgation of the laws that govern it.

There are three competing religions in Nigeria - Islam, Christianity and African Traditional Religion (ATR). These competing ideologies jostle for space in the mind of about 180 million Nigerians. It should be noted, however, that Islam and Christianity are the dominant religions. It is very difficult, if not impossible, to put the religious demography of the country into figures, due to religious politics and the politics of religious statistics in the country. The general opinion is that Muslims are predominant in the North, while Christians dominate the South. ${ }^{20}$

\section{Islamic groups in Nigeria}

Islam was introduced into the country through the North and the trans-Saharan trade through the desert of North Africa. Since its introduction, it has spread

18 Furseth and Repstad, Introduction to the Sociology of Religion, 91.

19 Berger, "Epistemological Modesty", 978.

20 See Adogame A. 2011. "How God became a Nigerian: Religious Impulse and the Unfolding Nation", in Obadare E and Adebanwi W (eds). Nigeria at Fifty: The Nation in Narration. London: Routledge. 
all over the country. Missions and groups have emerged, propagating Islamic tenets and doctrines. The groups could be divided into three: (1) mission groups (e.g. Ansar-Ud-Deen Society, Nawal-Ud-Deen Society, Zumratul-ul Islamiyah Society), (2) spiritualist groups, who engage in healing and soothsaying for the patrons (such as that of of Shaykh Abdul Hamid Olohungbemi, founder of Shamsu-d-diniil-Islamiyyah ${ }^{21}$ ) and (3) the so-called Islamic "Pentecostals" (e.g. Nasru-Lahil-Fatil Society (NASFAT), Quareeb Society (QUAREEB), NadwatulAhli Society of Nigeria (NADWAT)). ${ }^{22}$ The last group is popular in South West Nigeria where prayers and lectures are organised every Sunday for the faithful. This is what Nigerian religion scholar Abdul Lateef Adetona refers to as the "prayer market". ${ }^{23}$

It should also be noted that Islam and Muslims in Nigeria have used religion as a tool of social identity, political negotiation and economic empowerment. This has led to establishment of groups among students and youths in secondary and tertiary institutions. An example is the (MSSN) to spearhead agitation for emancipation of Muslim youths in the Nigerian polity. Women's groups, such as Federation of Muslim Women in Nigeria (FOMWAN), were also created to seek for the recognition of women in the country. These groups educate Muslims on their social and political rights and encourage Muslims to be active in politics and economic discourses in the country. These groups have become active in the political development of the country. For example, during military rule in Nigeria (1983-1999), Muslims were among those who agitated for the institution of democracy. In this regard the Supreme Council for Islam in Nigeria (SCIN) and National Council of Muslim Youth Organisations (NACOMYO) were in the forefront of the movement. In Nigeria, it would seem the Muslims are more unified compared to the Christians in the "spiritual marketplace".

\section{Christian groups}

Christianity was introduced to Nigeria by the mission groups in 1842. Since then, various groups have emerged. These groups have been major social and political advocators in the country. Prime examples of these groups include the African Independent Churches (AICs) and the Pentecostal and charismatic churches. Some of these groups emerged from the mission churches. And, indeed, in the socio-political front, Christian churches played a pivotal role in

21 See Bello MA. 2002. Shaykh Abdul Hamid Olohungbemi and His Dawah Activities in Ado Odo (Ogun state) and Its Environs, MA Thesis, Lagos State University.

22 Adetona LM. 2005. "Role of Muslim Youth in the Implementation of Shariah in Contemporary Nigerian Society". Paper presented to the African Association for the Study of Religions, Legon, Ghana. See also Sanni A. 2004. "Prayer Youth Movement - A case of NASFAT". Paper presented at the African Association for the Study of Religions regional conference, Legon, Ghana.

23 Adetona LM. 2012. "NASFAT: A Modern Prayer Group and its Contributions to the Propagation of Islam in Lagos", World Journal of Islamic History and Civilization 2(2):164. 
the movement for Nigeria's independence. Christian churches have continued to seek good governance, corruption-free leadership and good social values for the country. The efforts of the Christian groups are often publicised through the umbrella of the Christian Association of Nigeria (CAN) and the Pentecostal Fellowship of Nigeria (PFN).

It should be noted that there is competition, even among the Christian groups, for the soul of the people. Thus, we can talk about pluralism even among the Christians in Nigeria. Christian groups have turned Nigeria into a spiritual marketplace where "religious trade fairs" are organised regularly to "cater" to the needs of the people. The Christian groups have taking their "wares" to the electronic media, buying airtime for preaching and converting souls. They often give phone numbers, email addresses and internet websites where they can be contacted for prayers. This situation, arguably, has weakened the focus of the groups and made the Christian tradition a means to prosperity, social relevance and empowerment for the leaders, while the congregations continue to wallow in poverty, ignorance, unemployment and disease. To confront these problems, Christians in Nigeria have continuously moved from one church to another in a pluralised Christian environment seeking "products" in a "religious department store", where salvation, miracles, prosperity and healing are the major "goods" on display".

\section{African traditional religions}

The third religious tradition in Nigeria is African traditional religion, popularly referred to by many scholars as African Traditional Religion (ATR). This religion has dominated the politics, economics, social and cultural landscape of the people of Nigeria before the advent of Islam and Christianity. It should be noted however, that there still are Nigerians who are patrons and adherents of these religions, even though few. Though there is little demographic data to support this claim, it seems to be the case that the membership base of the ATRs is not increasing as fast as that of the Muslims and Christians. My hypothesis here is based on anecdotal evidence from my 21 years of research of these groups. These religions have been organising and modernising their traditions, so as to attract patronage. In fact, for the last decade, 20 August every year has been declared Isese (traditional) Day by the Lagos State government, in deference to traditional religion in Lagos State. This is because Lagos due to its cosmopolitan nature is religiously diversified and pluralised. It should be noted that this is peculiar to Lagos.

There are many variations among the African traditional religious groups in Nigeria. Conservative groups tend to practice pristine forms of traditional religion. Liberal groups are sometimes accused of syncretism for combining traditional religion with Islam or Christianity. There are also those who, in the name of modernity, appropriate Islamic and Christian values to "sell" ATR to Nigerians. In this category, we have Ijo Orunmila Adulawo and Ijo Orunmila 
or Ato. These groups have appropriated Christian liturgy as part of their tenets and doctrines. They have a creed, hymnbook and standing choir, with leadership patterned after the Anglican Church structure. There is also a notable "syncretic" group known as Chrislamherb. Found among the Yoruba people, this group blends Islam and Christian traditions with ATR. It is interesting to note that the traditional religious groups have become significant forces in the attempt to occupy and dominate the Nigerian religious space.

\section{NEW PLURALISM AND ENGAGED SECULARISM IN THE NIGERIAN RELIGIOUS SPACE}

It may not be wrong to claim that Nigeria is a hub of religious rituals and practices on the African continent. Religions in Nigeria play deterministic roles in politics, economy and social engagement of the leaders and followers in a country that claims to be secular. This is also true of government formulation of laws and policies. We can therefore argue that Nigeria is a religiously pluralistic country, where multiple religious traditions compete for the mind of the populace.

This perhaps may contradict the aforementioned constitutional position that Nigeria is a secular state. While it is true that the state has not adopted any religion as official, the rulers have continuously appropriated religious values in policy formulation and implementation. Eleven days are declared public holidays in Nigeria for religious reasons. Political processes and programmes must give due recognition to religion for them to be acceptable to the electorate. For example, it has become a tradition for political parties in Nigeria to always apply "religious balance" in the selection and presentation of candidates for electoral offices.

The idea that pluralism is the cause for secularisation cannot hold true in Nigeria. While religious pluralism can lead to secularisation, or separation of religion and state according to the American model, it cannot be true of the developing nations in Africa as the Nigerian example has shown. On the contrary, secularism in Nigeria allows for and at times manipulation of the values of more than one religion in the making of government policies, legislations and programmes, so that government maintain balance among all religious epistemologies in the polity. This policy of what might be called "engaged secularism" is different from the theories on secularism as discussed above. It is a new model that called for further academic engagement.

Syncretism is one of the attendant effects of religious pluralism. This concept suggests a combination of two or more religious traditions to form one. In fact, in an environment where there are many religions showcasing their "wares", there is bound to be syncretism, since the "needs" of the people will determine what they will "buy" in the "spiritual supermarket". As mentioned earlier, Nigerians are faced with the problems of hunger, disease, ignorance, spiritual 
attacks and bad governance, among others. Any religion that "displays" solutions to these problems will be patronised by the people.

To examine this phenomenon, research undertaken for the analysis here included a structured questionnaire administered in Lagos by the present writer and some postgraduate students among selected educated upward mobile religious youth between the ages of 25 and 45 . About $65 \%$ of the respondents to the questionnaire on this issue agreed that they patronise more than one religious group to tackle the challenges confronting them. A solid 30\% claimed they are committed to the tenets and doctrines of their religion as a solution to these problems. The other $5 \%$ are not bothered about the situation and feel that spiritual solutions to social and economic problems will come naturally.

Therefore, the Nigerian situation suggests that there is no religious monopoly in responding to the myriad of problems facing the country. A combination of two or three religious "wares" may bring the ideal solution to the problems of the people. In a religiously plural society like Nigeria, people will adopt and appropriate multi-religious panaceas to their spiritual and material problems. Where there are alternative epistemologies, people tend to seek multiple solutions to issues confronting them. The implication is that no one religion has solutions to the multi-faceted problems of the modern world. The crux of the matter is to determine how religious groups respond to government policy formulations and how government has often responded to agitations for withdrawal of its policies when it seem to affects the beliefs, doctrines and rituals of some religious groups. The Coroner Law System in Lagos State is an excellent case study for understanding this dynamic.

\section{RELIGION AND GOVERNMENT POLICY AND LAW FORMULATIONS: THE CASE OF THE CORONER LAW SYSTEM IN LAGOS STATE}

The Lagos State House of Assembly (LSHA) enacted the Coroner Law System to regulate the process of death investigations and other related matters in the state. The law became operational in 2007, forty years after the creation of the state. A Chief Coroner, Chief Medical Examiner and District Medical Examiners are to be appointed to oversee the implementation of the law. The Chief Coroner (CC) is at the head of the implementation team. The Chief Medical Examiner (CME) is responsible to the (CC), and it is he who determines the cause and circumstances of death. The District Medical Examiners (DMEs) are to work with the CME from the five divisions of the state. Section 14 of the CLS stipulates that a report of death shall be made to the office of the coroner and that deaths may be subjected to postmortem examination where there is reasonable cause to believe that the cause of death was unknown, sudden, unexpected and unnatural. It also involves situation of unreported death, violent, suspicious, accidental, self-neglect, negligence by others, due to medical misconduct, suicide, suspected suicide or assisted suicide. 
Section 15 of the CLS mandates that the Coroner hold an inquest whenever he is informed that the death of a deceased person lying within his coroner district was a result of death from one of the possible causes mentioned in Section 14. The Coroner is also empowered by the CLS to order exhumation of bodies that have been buried without postmortem with prior authorisation of the medical examiners, especially in cases where inquest is necessary. Further, Section 23 of the CLS makes it mandatory that all deaths should be reported to the appropriate coroner agencies. This includes deaths of family members and people in the community, as well as death in police custody or jail or in medical hospice. Section 28 permits the medical examiners to perform a postmortem for the purpose of establishing the cause and manner of death, even if it requires retaining any human tissue or other parts from the body of a dead person. In such cases, the medical examiner should apply and obtain the consent of the Coroner and next of kin of the deceased person.

The above are some of the provisions of the CLS. The law became operational in Lagos in 2007 and immediately became a subject of debate among religious groups in Lagos. Muslims have been vehement in their opposition to the implementation of the law. To them, it is against the traditions and doctrines of Islam in relation to death and funeral rites of Muslims. In Islam, a dead person is expected to be buried immediately after death regardless of the time of death. This requirement precludes conducting a postmortem investigation to determine the cause of death. The underlying belief is that Allah gives life at birth and takes it at death. Further, all parts of the body at the time of death must be buried as part of the funeral rites. Consequently, the retention of tissues or other parts of the body, as specified by the CLS, is against Islamic traditions on funeral rites. According to Abdul Lateef Adetona, one of the three imams of Lagos State University's mosque, the enactment of the CLS did not take into cognisance the feelings of Muslims in the state. ${ }^{24}$

In the opinion of Muslim Mahmud of Okepopo Quranic Mosque, the CLS is anathema to Islamic traditions as mentioned above; however, he admitted that the CLS did not violate any specific injunction of the Quran. ${ }^{25}$ In his opinion, the Islamic traditions on burial and funeral rites are based on Arab customs and traditions of the prophet. According to these traditions, Muslims bury their death on the same day that the death occurs or if late in the night, then the next morning. Decomposing corpses can also cause environmental and health hazards to the community, thus the tradition of immediate burial. Ustaz Kabir Paramole, the Chief Missioner of Jejewiyyat Islamic Movement in Lagos suggested that the CLS cannot be sustained in a pluralistic and cosmopolitan

24 Interview with Abdul Lateef Adetona by D Oguntola-Laguda, Ojo, Badagry Division of Lagos State, Nigeria, February 2009.

25 Interview with Muslim Mahmud by D Oguntola-Laguda, Lagos Division, Lagos State, Nigeria, February 2009. 
society like Lagos. ${ }^{26}$ In his opinion, the formulation of the CLS law should have considered the religious persuasions of the population. He was not surprised that Muslims in the state opposed the implementation of the law from the outset, and when it was withdrawn for review by the governor, he felt the agitation of the Muslims in this regard must have yielded positive results.

Tunde Bajulaye, one of the law officers in the Lagos State Ministry of Justice, opined that there was nothing wrong in the formulation and implementation of the CLS. ${ }^{27}$ In his view, the law was put in place by government to check the excesses of law enforcement agencies, such as the police, with regard to deaths in their custody, cases of unreported death and deaths due to negligence, among other causes. The state is secular and does not make religious beliefs and practices a factor in its policy-making process. Nonetheless, the Muslims should protest the implementation of the law in court. Since the law was introduced, no Muslim groups or individuals have so far sought judicial redress against the implementation of the CLS in the state.

Christians are not against the CLS. They do not see anything wrong with its implementation in the state. However, one interviewee, Kehinde Babarinde, a pastor at Satellite Baptist Church in Lagos, opined that the only snag in the CLS is the retention of parts of the deceased body by the medical examiner for possible future analysis. In his view, this is not necessary. ${ }^{28}$ Rather, the state should put in place machinery that will make an inquest or postmortem brief and thoroughly completed within a short time.

But the CLS law remains problematic from the Muslim perspective. The national coordinator of Muslim Right Concern (MURIC), Lakin Akintola, believes CLS is a violation of the right of Muslims to decent burial as dictated by Islamic traditions. He has therefore championed the call for the abrogation of the CLS in Lagos. ${ }^{29}$ The Lagos State Government reacted to the numerous agitations and protests against the implementation of the CLS by withdrawing the law for further review. The CLS was reintroduced in 2010 with modifications to respect the funeral and burial rites of Muslims in the state.

\section{ANALYSIS OF RELIGIOUS RESPONSES TO THE CLS LAW}

In course of the study that underlies the present analysis, we collected data using questionnaire and oral interviews to analyse the religious responses to the CLS law. We distributed questionnaires and conducted 50 oral interviews

26 Interview with Ustaz Kabir Paramole by D Oguntola-Laguda, Ojo, Badagry Division, Lagos State, Nigeria, November 2009.

27 Interview with Tunde Bajulaye by D Oguntola-Laguda, Ikeja, Ikeja Division, Lagos State, Nigeria, July 2008.

28 Interview with Kehinde Babarinde by D Oguntola-Laguda, Satelllite Town, Badagry Division, Lagos State, Nigeria, February 2009.

29 Interview with Lakin Akintola by D Oguntola-Laguda, Iba Town, Badagry Division, Lagos State, Nigeria, February 2009. 
with Muslims and Christians in Lagos State. The intention was to seek their opinion on how the CLS affected the practice of their religious traditions on funeral rites. Our focus was on Muslims in Lagos, since Muslims voiced the greatest number of objections to the law; however, we also interviewed five Christian clerics. Questionnaires were administered among Muslims in the five divisions of Lagos state. Ten thousand of these questionnaires were distributed in the five divisions of the state evenly among the five regions of Epe, Ikorodu, Badagry, Lagos and Ikeja, and 8,436 were returned. ${ }^{30}$ The questionnaires were administered during Jumat prayers which Muslims in Lagos State attend religiously.

The study revealed that illiterate Muslims in Lagos State were not even aware of the CLS. It was only the leaders of Muslim groups who seemed to know of its existence. It was further observed that the illiterate Muslims continued to practice their normal funeral rites without any recourse to the CLS during the brief period it operated. For them, death and burial practice was "From Allah we come and to Him we shall return". But this lopsided distribution of awareness does not demonstrate that religious leaders do not have influence on their followers. In fact, it strongly suggests that leaders could exploit this gap to frustrate the implementation of government policies in the state. Further, part of the problem government encountered then was that government did not adequately research into the sensitivities of religious adherents before the introduction of the CLS. This is confirmed by the following further results of the study.

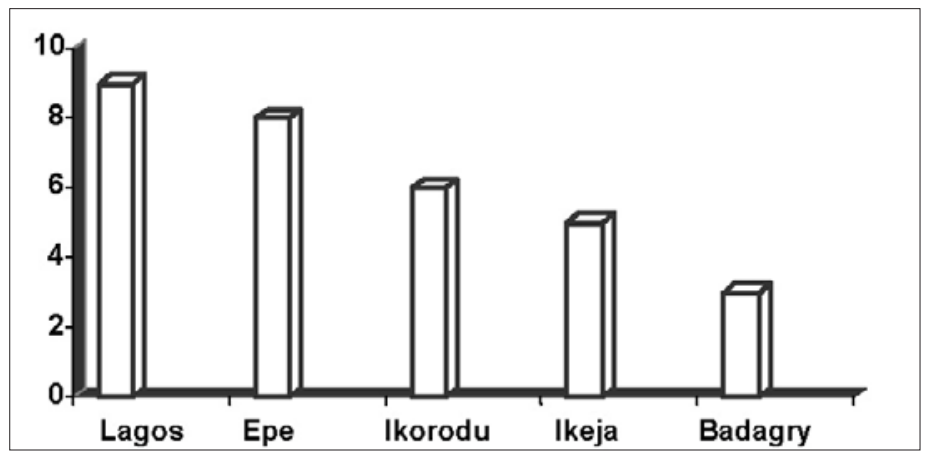

Figure 21.1: Level of awareness about CLS

30 It is perhaps worth noting that these divisions are for administrative convenience of the government of Lagos Sate and have been in place since inception of the state in 1967. The population of Lagos State alone has a population of nearly five million people, and these divisions have a reasonable population of over 800,000 . Postgraduate students distributed these questionnaires, and brought back the 8,436 completed questionnaires from their respondents. The questionnaires were administered during Jumat prayers which Muslims in Lagos State attend religiously. 
The graph distribution in Figure 1 shows that the CLS was more popular in the Lagos division than all other divisions. Badagry displayed the lowest knowledge of the CLS. Muslims in this division were not even aware of the enactment of the CLS, as they continued to bury their death without reporting to the appropriate authorities as stipulated by the law. It should be noted that Muslims in Badagry division are not many compared to Christians. Even those who claimed to be Muslims were syncretic and still patronised traditional religious ceremonies and festivals. In this regard, they are not strict in the application of Islamic funeral rites during burial of the dead. Some even combined the burial rites of ATR with those of Islam. The effect was that they did not necessarily bother about the implications of the CLS in the funeral rites and rituals of their Muslim brothers and sisters. In Epe, most (64\%) of our respondents were aware of the CLS and voiced their opposition to it through numerous Islamic groups in Lagos State, as well as among the five divisions. The scenario was not different in Ikeja. However, we observed that the cosmopolitan nature of this division might have been a determining factor about their knowledge and awareness of the CLS. Ikorodu is a division where Muslims are highly syncretic, as in Badagry. They hardly ever attend Jumat service and belong to numerous secret societies of ATR that pervade the area.

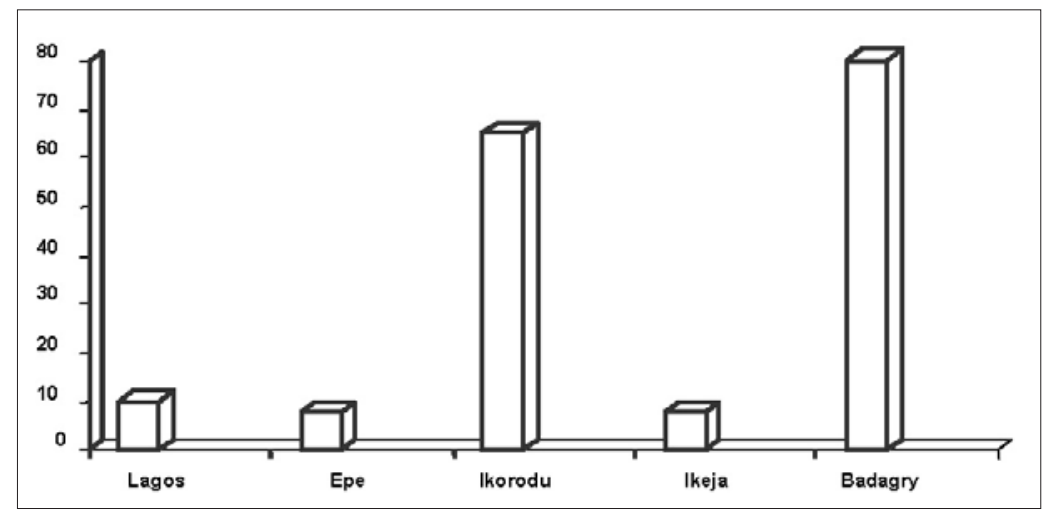

Figure 21.2: Would you allow postmortem?

Muslims in Lagos, Ikeja and Epe would not tolerate a postmortem or inquest about their deceased ones. To them, it is against Islam. They also rejected the idea that the medical examiner reserved the right to retain part of the body of the deceased. In Badagry and Ikorodu, those who claim to be Muslims are not keen on this requirement of the CLS. To them, if it is necessary and imperative they should be done otherwise they careless. 


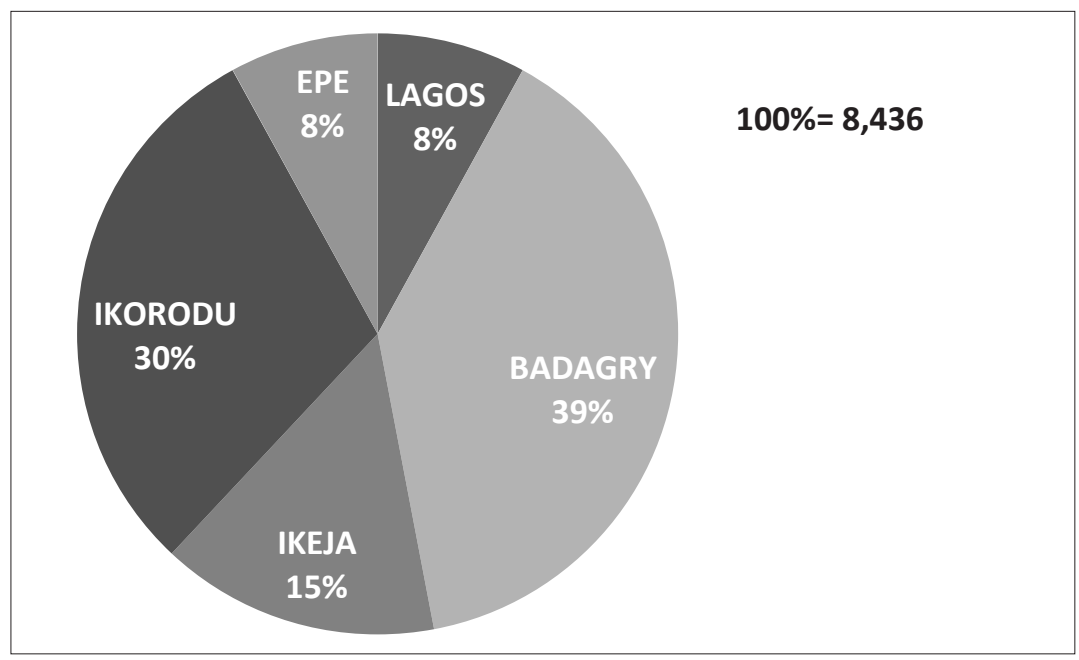

Figure 21.3: Would you want the CLS reintroduced in its old form?

Our respondents in Lagos are not comfortable with the CLS in its old form and therefore called for a review. Of the survey respondents, 91\% acknowledged the necessity of the CLS, but they advised that the CLS should take Islamic traditions, tenets and laws into consideration. The same response was derived from Ikeja, with an even higher percentage of $95 \%$. Epe division did not want the CLS at all, only legislation to regulate death from dubious causes. Ikorodu and Badagry were not particularly bothered about the CLS. Thus $65 \%$ and $62 \%$ of our respondents respectively in Badagry and Ikorodu would want the old CLS.

\section{CONCLUSION}

Nigerians are incurably religious. This same mentality is often carried into political engagements. This is reflected in the way religious traditions and tenets have influenced government policies in the country as a whole, even though the country is supposed to be a secular state. This chapter demonstrates that secularism does not suggest non-religiosity, but rather an attempt to push religion out of public domain and to reject its deterministic tendencies regarding state laws and policies. This was the case with the Coroner Law System 2007 before its withdrawal. It further shows that government formulation of laws and policies in a religiously plural state like Nigeria must always put into consideration the doctrines, beliefs, and rituals of competing religious traditions. This was the case when the CLS reintroduced in 2010, with modifications of those sections that were against the funeral rites of Muslims, except for deaths in police custody or prisons, which were still required to be subject to postmortem investigation.

In a religiously heterogeneous state, the scenario would have been different. The CLS would have considered the religious rites as well as the sensibility of the people in formulating the law. The case of the CLS is an example of 
how religious doctrines, tenets and traditions have affected the formulation of laws and government policies meant for the good of the society. Incidents of dubious deaths, especially in police custody, which are rampant in Lagos, need to be verified by the coroner at an inquest, so that the cause of death can be determined and appropriate sanctions placed on erring police officers, government officials and other persons involved in such deaths.

Due to religious doctrines and beliefs, particularly Muslim objections to the CLS, the law was withdrawn in 2008, following protests and outcries from Muslims in the state. It should be noted that the law has since been reintroduced, and because the government has been silent on its implementation, there has not been any notable protest against it. However, it has been applied to several cases of death in public spaces and religious institutions. The case of SCOAN as earlier mentioned in this chapter is an example. The case of the Dana Air plane crash in 2013 is also a reference point in the implementation of the modified CLS. In these two instances, unsubstantiated reports suggest that Muslims were among the dead. 